\title{
Kemampuan Konservasi Panjang Pada Siswa Usia 6-7
}

\author{
Apolonia Hendrice Ramda ${ }^{1}$, Rully Charitas Indra Prahmana ${ }^{2 *}$, Hildegardis Mulu \\ Bedilius Gunur ${ }^{4}$ \\ ${ }^{1,3,4}$ STKIP Santu Paulus Ruteng, Kabupaten Manggarai, Nusa Tenggara Timur 86511, Indonesia \\ ${ }^{2}$ Universitas Ahmad Dahlan, Kota Yogyakarta, DI Yogyakarta 55166, Indonesia
}

Pengiriman: 31 Juli 2018; Diterima: 29 September 2018; Publikasi: 30 September 2017

DOI: https://doi.org/10.31629/jg.v3i2.480

\begin{abstract}
Abstrak
Penelitian ini bertujuan untuk mendeskripsikan kemampuan konservasi panjang pada siswa yang memiliki usia 6-7 tahun di Kabupaten Manggarai. Penelitian ini merupakan penelitian deskriptif kualitatif dengan sampel yang diambil secara acak sejumlah 80 anak. Siswa yang berusia 6 tahun berjumlah 40 anak, begitu juga dengan siswa yang berumur 7 tahun, yang diambil dari SD di Kabupaten Manggarai. Instrumen yang digunakan dalam penelitian ini berupa angket konservasi panjang yang berisi pernyataan-pernyataan mengenai berbagai kondisi yang menjelaskan konsep konservasi panjang. Setiap anak diberi tes kemampuan konservasi panjang kemudian dilanjutkan dengan wawancara mengenai alasan memberi jawaban pada tes konservasi tersebut. Hasil penelitian menunjukkan bahwa golongan konserver pada siswa yang berusia 6 tahun sebesar $0 \%$ dan 7 tahun sebesar 7,5\%. Selanjutnya, golongan konserver parsial pada siswa yang berusia 6 tahun sebesar 7,5\% dan 7 tahun sebesar 22,5\%. Selain itu, untuk golongan non-konserver pada siswa yang berusia 6 tahun sebesar 92,5\% dan 7 tahun sebesar 70\%. Hasil ini menunjukkan kemampuan konservasi panjang pada siswa yang memiliki usia 6-7 tahun di Kabupaten Manggarai masih rendah dan sebagian besar belum memahami konsep konservasi panjang.
\end{abstract}

Kata kunci: konservasi panjang; siswa usia 6-7 tahun; deskriptif kualitatif

\begin{abstract}
The purpose of this study was to describe the ability of Manggaraian children of age six to seven in length conservation area. This research is a qualitative descriptive study. The random sampling technique was used to select 80 children, consisted of 40 children per age. The instrument of this research was a length conservation questionnaire containing statements about conditions that explain the concept of length conservation. Each child was given a length conservation skill test followed by an interview about the reasons for providing answers to the conservation test. The results showed that none of six-year-old children was conserver, only $7.5 \%$ were partial conserver, and $92.5 \%$ were non-conserver. For seven-year-old children, $7.5 \%$ were conserver, $22.5 \%$ were partial, and $70 \%$ were non-conserver. These results indicate the lengthy-term conservation ability of children age six to seven in Manggarai Regency is still low and most have not understood the concept of length conservation.
\end{abstract}

Keywords: length conservation; student of age 6 to7; qualitative descriptive

\section{Pendahuluan}

Istilah konservasi pertama kali

diperkenalkan oleh Piaget. Piaget dalam teori

perkembangan kognitif anak yang

*Penulis Korespondensi 


\section{JURNAL GANTANG. September 2018; III(2): 109 - 116 \\ p-ISSN. 2503-0671 \\ e-ISSN. 2548-5547}

dikemukakannya, memperkenalkan istilah konservasi sebagai bentuk tingkatan kognitif anak yang sangat dipengaruhi oleh umur. Konservasi menjadi bagian esensial dalam teori tersebut. Piaget dalam Funny (2014) mengungkapkan konservasi sebagai sesuatu yang mempertahankan struktur yang tetap tidak berubah walaupun terjadi perubahan aspek objek tersebut. Piaget mengemukakan bahwa cara berpikir anak berbeda dari orang dewasa. Setiap anak akan melewati empat tahap perkembangan kognitif, yakni sensori-motor, pra-operasional, operasional konkret, dan operasional formal. Piaget mengemukakan bahwa cara berpikir anak berbeda dari orang dewasa. Setiap anak akan melewati empat tahap perkembangan kognitif, yakni sensori-motor, pra-operasional, operasional konkret, dan operasional formal. Menurut Piaget, konservasi akan muncul dalam tahap pra-operasional dan operasional konkret.

Dalam teorinya, Piaget (Bradford \& Kroeker, 2016) menjelaskan bahwa tahap praoperasional (2-7 tahun) ditandai dengan memiliki kemampuan pemahaman tentang simbol, mengaplikasikan logika sederhana mengenai simbol tersebut dan dapat menguasai reversibilitas serta identitas. Selanjutnya, pada tahap operasi konkret yaitu pada usia 7-12 tahun, anak telah memiliki kemampuan konservasi mengenai prinsip-prinsip dasar. Pemahaman yang maksimal mengenai prinsip-prinsip konservasi baru akan dicapai sekitar usia 11 sampai 12 tahun. Pemahaman terhadap prinsipprinsip konservasi dapat dicapai oleh anak secara bertahap sesuai dengan perkembangan kognitif pada setiap tingkatan umur seperti yang telah dikemukakan oleh Piaget.

Anak mulai memahami berbagai prinsip/konsep konservasi ketika memasuki usia 6 tahun atau lebih (Arumsari, Andreswari, \& Saparahayuningsih, 2014) . Pada usia tersebut anak umumnya telah memahami prinsip konservasi dasar namun belum mampu memahami kondisi konservasi yang lebih kompleks. Pemahaman terhadap prinsip konservasi ini beragam untuk tiap anak sesuai dengan kemampuan kognitif yang dimiliki.

Secara umum, Piaget (Ramlah, 2015) mengkategorikan konservasi (kekekalan) menjadi konservasi bilangan, panjang, materi, luas, berat, dan isi. Waktu pencapaian kemampuan konservasi tiap anak dapat berbeda untuk setiap budaya (kondisi lingkungan yang turut mendukung), akan tetapi pola pencapaiannya sama yaitu melalui tiga tahap. Tahap pertama non-konserver yaitu tahap yang mana anak belum memahami konsep konservasi. kedua transisi yaitu tahap yang mana pada kondisi tertentu anak memahami prinsip konservasi namum dalam beberapa situasi yang berbeda anak tidak memahami prinsip konsevasi. Tahap ketiga konserver, yaitu anak telah sepenuhnya memahami konsep konservasi.

Ketiga tahap pencapaipan konservasi ini sesuai dengan perkembangan kognitif anak. Seiring pengalaman dan kematangan, kemampuan konservasi sederhana yang dimiliki anak pada awal sekolahnya dapat membantunya dalam memahami konsep konservasi yang lebih kompleks (Lambert \& Spinath, 2018). Konservasi sederhana yang dimaksud berkaitan dengan manipulasi sifat-sifat dasar objek pada tingkat yang sederhana seperti panjang dan kuantitas dari objek tersebut. . Manipulasi objek tingkat sederhana menuju komplek merupakan salah satu bentuk kemampuan berpikir tingkat tinggi, diantaranya kritis dan kreatif yang sangat diperlukan dalam pemahaman konsep-konsep matematika (Makur, Prahmana \& Gunur, 2018; Mann, 2014; Nafiah, Suyanto, \& Yogyakarta, 2014). Selain itu pemahaman terhadap konsep matematika akan lebih mudah dipahami apabila pembelajaran matematika disajikan dengan mengaitkan konsepnya dengan masalah kehidupan sehari-hari (Tik, 2014; Crowley, 2015; Izzati, Ahmad, \& Abu, 2010). Mengaitkan konsep matematika dengan kehidupan seharihari siswa ini merupakan pendekatan yang dilakukan untuk mengukur kemampuan konservasi anak.

Setelah anak memahami sifat dasar dari manipulasi objek, pemahaman tersebut akan 
membantunya untuk tingkat manipulasi objek yang lebih komplek maupun rumit seperti liquid, volume, ataupun berat. Konsep konservasi merupakan konsep dasar untuk mempelajari matematika. Setiap anak memiliki karakter dalam belajar matematika yang sesuai dengan kemampuan kognitifnya dan tingkat kesulitan belajar yang dimilikinya (Yáñez-marquina \& Villardón-gallego, 2016; Khuziakhmetov \& Gorev, 2017; Novitasari, 2016). Kemampuan kognitif ini menentukan prestasi anak di sekolah bahkan sikap dan tindakannya dengan lingkungannya (Yee et al., 2015; (Ladd, Ettekal, \& Kochenderfer-ladd, 2017). Hal ini juga berpengaruh terhadap prestasinya dalam matematika (Opolot-Okurut, 2010). Namun, Jika anak telah mencapai pemahaman akan manipulasi sifat objek baik sederhana maupun kompleks maka anak siap untuk belajar matematika.

Hal ini juga didukung Funny (2014) dalam hasil penelitiannya, yang menyatakan bahwa proses pembelajaran matematika akan lebih mudah diikuti anak apabila telah memiliki pemahaman konservasi yang baik. Pemahaman tentang konsep konservasi akan mempermudah anak dalam manipulasi objek matematika. Karena itu penting dilakukan identifikasi terlebih dahulu berkaitan dengan kemampuan konservasi siswa sehingga guru mempunyai gambaran terhadap kemampuan awal siswa. Dengan demikian guru dapat merancang pembelajaran yang tepat sesuai dengan kondisi anak dalam kelas, dalam hal ini berkaitan dengan kemampuannya. salah satunya dengan menerapkan permainan matematika. Permainan matematika dapat digunakan untuk mengetahui kemampuan konservasi anak. Permainan matematika juga dapat membangun pemahaman, pengetahuan, dan ketertarikan terhadap matematika (Bobis, 2010; Kaune, Nowinska, Paetau \& Griep, 2013 ; Lowe, 1988; Kaune et al., 2013).

Kemampuan anak berbeda-beda pada setiap tahapan perkembangan kognitifnya, begitu pula dengan kemampuan konservasinya. Karena pada dasarnya kemampuan kognitif anak menentukan tingkat kemampuan konservasinya (Ashley-Smith, 2016). Perkembngan kognitif berkaitan dengan umur, hal yang sama pula berlaku pada kemampuan konservasi. Berdasarkan teori dan hasil penelitian tersebut, seharusnya anak usia 6-7 tahun yang termasuk dalam masa transisi dari kategori pra-operasional menuju operasional konkret sudah memiliki kemampuan konservasi. Bahkan, kelompok anak tersebut seharusnya sudah diperkenalkan dengan aktivitas terkait konservasi ketika mereka masih di jenjang Taman Kanak-Kanak. Akan tetapi, di kabupaten Manggarai belum dilakukan analisis secara mendalam mengenai hal tersebut. Untuk itu, penelitian mengenai analisis kemampuan konservasi anak usia 6-7 tahun se-Kabupaten Manggarai sangat penting dilakukan. Kemampuan konservasi yang dianalisis dibatasi pada konservasi panjang. Hasil penelitian ini dapat digunakan sebagai salah satu dasar untuk merancang pembelajaran matematika yang tepat bagi anak di sekolah, khususnya yang melibatkan banyak aktivitas. Selain itu, hasil tersebut juga dapat dijadikan sebagai masukan untuk penyelenggaraan program pra-sekolah agar memunculkan aktivitas yang membangun kemampuan konservasi anak.

\section{Metode Penelitian}

Penelitian ini adalah penelitian deskriptif kualitatif, yaitu mendeskripsikan kemampuan konsevasi panjang anak usia 6-7 tahun seKabupaten Manggarai. Penelitian ini dilakukan di dua puluh Sekolah Dasar yang tersebar di Kabupaten Manggarai. Peneliti bekerja sama dengan pihak sekolah untuk memudahkan dalam pengambilan sampel khususnya disesuaikan dengan umur anak. Selain itu juga dengan mengambil siswa sebagai subyek penelitian dapat membantu guru untuk mengetahui gambaran mengenai kemampuan konservasi panjangnya. Sampel penelitian diambil secara acak berjumlah 80 anak, masing-masing 40 anak disetiap usianya. Anak usia 6 tahun terdiri dari 29 perempuan dan 11 laki-laki. Sedangkan anak 


\section{JURNAL GANTANG. September 2018; III(2): 109 - 116 \\ p-ISSN. 2503-0671 \\ e-ISSN. 2548-5547}

usia 7 tahun terdiri dari 29 perempuan dan 11 laki-laki.

Instrumen yang digunakan dalam penelitian ini adalah tes konservasi panjang yang dilengkapi dengan wawancara tidak terstruktur. Tes tersebut berupa pertanyaan-pertanyaan untuk mengetahui seberapa jauh pemahaman anak mengenai konsep konservasi panjang. Pertanyaan berupa "apakah sama atau tidak ...?" dan "manakah yang lebih ...?" diajukan untuk beberapa kondisi benda selama berlangsungnya tes konservasi. Selanjutnya wawancara tidak terstruktur dilakukan untuk mengetahui lebih dalam mengenai alasan anak menjawab setiap pertanyaan yang diberikan.

Peneliti melakukan wawancara kepada setiap anak sebagai sampel penelitian di SD. Secara keseluruhan, setiap subjek diwawancara secara personal sebanyak dua kali, masingmasing untuk setiap jenis konservasi. Objek yang digunakan untuk tes konservasi adalah tali.

Secara umum, tes konservasi panjang dengan objek tali mengikuti 4 tahapan. Pertama, kedua objek ditempatkan dalam kondisi sama persis. Kedua, dilakukan manipulasi pada satu objek. Ketiga, reversibilitas, yakni mengembalikan kondisi objek seperti semula. Keempat, dilakukan manipulasi yang berbeda dari manipulasi pertama yang dilakukan pada satu objek, Kemudian pada tahapan akhir, pengembalian kondisi objek ke kekeadaan semula.

Hasil tes konservasi panjang terhadap anak usia 6-7 tahun dianalisis dan digolongkan ke dalam 4 kategori, yakni konserver, konserver parsial, non-konserver, dan tak dapat diklasifikasikan. Penggolongan ini berdasarkan jawaban subjek pada 4 tahapan umum dalam setiap tes. Subjek dikategorikan sebagai konserver jika mampu menjawab benar dalam dua situasi, yakni menjawab "sama" pada tahap kedua dan keempat. Subjek akan digolongkan sebagai konserver parsial jika hanya menjawab benar pada salah satu situasi. Jika menjawab salah untuk kedua situasi, yakni menyatakan bahwa kedua objek tidak sama sifatnya (salah satunya lebih dari yang lain), maka subjek akan diklasifikasikan sebagai non-konserver, atau belum memahami konservasi. Sedangkan, jika dalam 5 tahapan tersebut subjek tidak memberi jawaban yang jelas, atau salah menjawab sejak tahap pertama, yaitu ketika belum dilakukan transformasi objek, maka subjek tidak dapat diklasifikasikan.

Selanjutnya, peneliti juga mewawancarai anak mengenai alasan memberikan jawaban pada setiap tes, terlepas dari benar atau tidak jawabannya. Alasan tersebut kemudian diklasifikasikan kedalam 5 kelompok, yakni konservasi, menghitung, persepsi, tidak relevan, dan tidak ada respons. Digolongkan kedalam konservasi jika anak menggunakan logika konservasi, yakni menyadari bahwa manipulasi kondisi objek tidak mempengaruhi kuantitasnya. Jika dalam menjawab tes konservasi panjang anak menghitung untuk dapat mengetahui ketetapan kuantitas objek, maka alasannya adalah menghitung. Apabila anak memberi alasan berkaitan dengan bentuk visual, maka dikategorikan sebagai persepsi. Jika alasan yang dikemukakan anak tidak relevan dengan jenis konservasi, misalkan menggunakan pencacahan (menghitung) atau jika jawabannya tidak logis, maka jawabannya tergolong tidak relevan. Sedangkan, apabila anak tidak memberi jawaban, maka dimasukkan dalam kelompok tidak ada respons. Akan tetapi, meskipun ditanyai alasannya, alasan tersebut tidak dijadikan sebagai dasar penggolongan subjek sebagai konserver atau non-konserver.

\section{Hasil dan Pembahasan}

Hasil data dirangkum dan dianalisis dalam tabel 1. Sebagian besar anak usia 6-7 tahun belum memiliki kemampuan konservasi panjang. Pada usia 6 tahun banyaknya anak yang tergolong sebagai konserver kurang dari 50\%.

Anak-anak yang tergolong dalam konserver parsial yaitu anak yang hanya menjawab benar pada salah satu tes yang diberikan. 
Tabel 1.

Distribusi kemampuan konservasi panjang

\begin{tabular}{|l|l|c|c|}
\hline \multicolumn{2}{|c|}{ Responden } & $\begin{array}{c}6 \text { thn (40 } \\
\text { anak) }\end{array}$ & $\begin{array}{c}7 \text { thn (40 } \\
\text { anak) }\end{array}$ \\
\hline \multirow{3}{*}{ Konserver } & $\begin{array}{l}\text { Banyak } \\
\text { Anak }\end{array}$ & 0 & 3 \\
\cline { 2 - 4 } & $\%$ & 7,5 & 30 \\
\hline \multirow{2}{*}{$\begin{array}{l}\text { Konserver } \\
\text { Parsial }\end{array}$} & $\begin{array}{l}\text { Banyak } \\
\text { Anak }\end{array}$ & 3 & 9 \\
\cline { 2 - 4 } & $\%$ & 22,5 & 30 \\
\hline \multirow{2}{*}{$\begin{array}{l}\text { Non- } \\
\text { Konserver }\end{array}$} & $\begin{array}{l}\text { Banyak } \\
\text { Anak }\end{array}$ & 37 & 28 \\
\cline { 2 - 4 } & $\%$ & 70 & 40 \\
\hline
\end{tabular}

Tes konservasi panjang yang diberikan terdiri dari dua situasi yaitu berkaitan dengan menentukan apakah masing-masing panjang 2 ballpoint yang sama dan 2 utas benang yang sama pula mengalami perubahan panjang atau tidak ketida benda-benda tersebut diubah susunan dan posisinya. Berikut adalah percakapan dengan salah satu Anak berinisial MJP usia 6 tahun, yang tergolong sebagai konserver parsial.

Sesi 1, peneliti menyediakan dua ballpoint yang sama panjang

Peneliti : Apakah dua ballpoint ini sama panjang atau tidak?

MJP : Ia, sama.

Peneliti : Nah, sekarang kakak geser ballpoint yang biru. Apa masih sama panjang?

MJP : Ia, sama panjang semua.

Peneliti : Mengapa begitu?

MJP : Karena hanya digeser, panjangnya tetap.

Sesi 2, Peneliti menyediakan dua utas benang wool yang sama panjang.

Peneliti : Apakah kedua benang ini sama panjang?

MJP : Sama

Peneliti : Ok, Kakak lengkungkan benang yang satu ini. Apakah keduanya masih sama panjang?

MJP : Tidak, yang dilengkungkan lebih pendek.

Peneliti : Mengapa begitu?

MJP : Panjangnya sudah tidak sama, yang dilengkungkan kelihatan lebih pendek.
Percakapan tersebut menunjukkan bahwa MJP tidak memahami konsep konservasi pada kondisi tertentu, dalam hal ini MJP tidak memahami bahwa walaupun salah satu tali dilengkungkan, panjangnya tetap sama seperti pada kondisi sebelum dilengkungkan. Sedangkan pada situasi ballpoint yang digeser, MJP mengungkapkan bahwa panjang ballpoint tersebut tetap sama seperti keadaan semula. Hal ini menunjukkan bahwa MPJ tergolong sebagai konserver parsial, yaitu memahami konsep konservasi hanya pada kondisi tertentu saja. Selanjutnya, berikut adalah percakapan dengan anak berinisial AM usia 6 tahun yang tergolong sebagai non-konserver.

Sesi 1, Peneliti juga menyediakan dua ballpoint yang sama panjang.

Peneliti : Apakah dua ballpoint ini sama panjang atau tidak?

AM : sama

Peneliti : Ok. Kalau ballpoint yang merah ini digeser, apa dua ballpoin ini sama panjang?

AM : Tidak. Yang digeser ini yang lebih panjang.

Peneliti : Mengapa begitu?

AM : Karena sudah digeser, berarti sudah lebih panjang.

Sesi 2, Peneliti menyediakan dua utas benang wool yang sama panjang dan diletakkan lurus di atas meja.

Peneliti : Apakah kedua utas benang ini sama panjang.

AM : Ia sama.

Peneliti : Ok, tali yang satu ini kakak lengkungkan. Sekarang, apakan kedua tali ini masih sama panjang?

AM : Tidak, yang ini lebih panjang. (sambil menunjukkan tali yg tidak dilengkungkan)

Peneliti : Mengapa begitu?

AM : Karena yang dilengkungkan lebih pendek, ukurannya lebih pendek.

Percakapan tesebut menunjukkan bahwa AM tidak memahami konsep konservasi. Pada kedua situasi yang berbeda tersebut, AM 


\section{JURNAL GANTANG. September 2018; III(2): 109 - 116 \\ p-ISSN. 2503-0671 \\ e-ISSN. 2548-5547}

mengungkapkan bahwa panjang ballpoint dan tali mengalami perubahan setelah diberi perlakuan (digeser dan dibengkokkan). Hasil ini tidak sesuai dengan yang diungkapkan oleh Piaget, bahwa anak usia 6 tahun seharusnya sudah memahami konsep konservasi panjang yang masih tergolong ke dalam konservasi sederhana.

Begitu pula pada anak usia 7 tahun menunjukkan hasil yang tidak jauh berbeda namun lebih tinggi dari usia 6 tahun. Hasil ini menunjukkan bahwa anak usia 7 tahun mempunyai kemampuan konservasi panjang yang lebih tinggi dibandingkan usia 6 tahun.

Berbeda dengan teori Piaget, hasil penelitian menunjukkan bahwa anak usia 6-7 tahun di Manggarai belum sepenuhnya menguasai konsep konservasi. Anak usia 6-7 tahun yang pada dasarnya sudah berada pada tahap operasional konkret, sudah mulai memahami konsep konservasi yang lebih kompleks, yakni panjang, liquid, dan substansi. Hal ini seperti yang dikatakan oleh Piaget bahwa anak-anak yang memasuki fase operasional konkret sudah memiliki kesadaran mengenai prinsip-prinsip konservasi, meskipun baru akan sempurna pada usia 11 atau 12 tahun.

Hasil penelitian ini sejalan dengan penelitian yang telah dilakukan sebelumnya yang menunjukkan bahwa kemampuan konservasi anak umumnya masih rendah (Funny, 2014; Ramlah, 2015; Arumsari et al., 2014; Lambert \& Spinath, 2018; Ashley-Smith, 2016). Dalam penelitian ini lebih dari 50 persen anak usia 7-8 tahun di kabupaten Manggarai (mengacu pada tabel 1) tergolong non-konserver. Meskipun waktu pencapaian kemampuan konservasi tiap anak dapat bervariasi, bahkan dapat berbeda untuk setiap budaya, akan tetapi pola pencapaiannya sama melalui tiga tahap, yakni: non-konserver (belum memahami konsep konservasi), transisi (kadang konserver, kadang bukan), dan konserver (sepenuhnya memahami konsep konservasi). Artinya, perbedaan hasil penelitian ini dengan beberapa hasil penelitian sebelumnya dapat dipengaruhi oleh berbagai faktor dan perlu diteliti lebih lanjut.

Selanjutnya berdasarkan alasan yang dikemukakan anak pada setiap tes, hasil penelitian secara mengejutkan menunjukkan bahwa pada konservasi panjang yang merupakan konservasi yang lebih kompleks, ternyata hanya 17 persen anak menjawab berdasarkan alasan konservasi. sebagian besar anak memberikan jawaban tes berdasarkan persepsi visual. Mayoritas anak masih menganggap bahwa media tali yang digunakan (untuk mengukur kemampuan konservasi) panjangnya tidak sama untuk setiap kondisi yang berbeda walaupun tali yang digunakan adalah sama. Tali tersebut diubah bentuknya kedalam kondisi yang berbeda-beda. Bentuk tali yang berbeda-beda memberikan persepsi visual yang berbeda-beda pula bagi anak. Anak menganngap bahwa panjang tali tidak sama karena bentuknya berbeda dari kondisi sebelumnya. Hasil ini jauh dari ekspekstasi karena untuk konservasi bilangan yang merupakan jenis konservasi paling sederhana, proporsi anak yang menjawab berdasarkan logika konservasi seharusnya lebih tinggi.

\section{Kesimpulan}

Secara umum, kemampuan konservasi anak usia 6-7 tahun di Manggarai masih rendah. Lebih dari $50 \%$ anak masing-masing usia tergolong non-konserver. Sedangkan, untuk setiap jawaban tes yang diberikan, alasan menjawab anak didominasi oleh persepsi visual dari kondisi objek, yakni lebih dari $75 \%$ dari total 80 anak. Hasil ini menunjukkan bahwa anak belum menguasai prinsip reversibilitas, yaitu menegasikan tindakan dengan cara melakukan tindakan yang sebaliknya dalam pikiran. Kenyataan ini tidak sesuai dengan teori yang dikemukakan oleh piaget bahwa anak usia 6-7 tahun yang berada pada tahap praoperasional dan operasional konkrit seharusnya sudah mampu memahami prinsip konservasi panjang.

Untuk melihat lebih jauh penyebab terjadinya hal tersebut, maka perlu dilakukan 
penelitian lebih lanjut berkaitan dengan penyebab rendahnya kemampuan konservasi panjang pada anak usia 6-7 tahun di Kabupaten Manggarai. Untuk Selain itu, dalam proses pembelajaran matematika peran guru sangat penting untuk memperkenalkan prinsip-prinsip konservasi sebelum memperkenalkan materi pelajaran karena prinsip konservasi pada dasarnya membantu siswa dalam memanipulasi objek-objek yang membantu dalam pemahaman konsep.

\section{Ucapan Terima kasih}

Terima kasih kepada kepala sekolah di dua puluh Sekolah Dasar Kabupaten Manggarai yang telah bersedia menerima peneliti untuk melakukan penelitian di tempatnya. Terima kasih pula kepada guru matematika kelas 1 dan 2 yang telah membantu peneliti selama penelitian berlangsung. Selanjutnya terima kasih kepada LPPM Santu Paulus Ruteng yang telah memberikan bantuan dana untuk kelancaran penelitian ini.

\section{Referensi}

Arumsari, L. E., Andreswari, D., \& Saparahayuningsih, S. (2014). Media permainan matematika menggunakan aplikasi java dekstop sebagai alat bantu pengajaran hukum kekekalan bilangan dan luas. Jurnal Teknologi Informasi, 10(2), 157-167.

Ashley-Smith, J. (2016). Losing the edge: the risk of a decline in practical conservation skills. Journal of the Institute of Conservation, 39(2), 119-132. https://doi.org/10.1080/19455224.2016.121 0015

Bobis, J. et al. (2010). Playing with mathematics: play in early childhood as a context for mathematical learning. In Shaping the future of mathematics education: Proceedings of the 33rd annual conference of the Mathematics Education Research Group of Australasia (pp. 714-730). Retrieved
https://www.researchgate.net/profile/Janett e_Bobis/publication/267414818_Playing_ with_Mathematics_Play_in_Early_Childho od_as_a_Context_for_Mathematical_Learn ing/links/5451270a0cf285a067c68480.pdf

Bradford, C. T., \& Kroeker, S. D. L. (2016). Educational psychology in Yukon. Canadian Journal of School Psychology, 31(3),

271-274. https://doi.org/10.1177/0829573516655230

Crowley, B. M. (2015). The effects of problembased learning on mathematics achievement of elementary students across time.

Funny, R. A. (2014). Students' initial understanding of the concept of conservation of area. Indonesian Mathematical Society Journal on Mathematics Education, 5(1), 57-65. Retrieved from http://search.ebscohost.com/login.aspx?dire $\mathrm{ct}=$ true $\& \mathrm{db}=$ eric $\& A N=\mathrm{EJ} 1079623 \&$ site $=\mathrm{e}$ host-live \&scope $=$ site

Izzati, N., Ahmad, R., \& Abu, R. (2010). The effects of problem based learning on mathematics performance and affective attributes in learning statistics at form four secondary level, 8(5), 370-376. https://doi.org/10.1016/j.sbspro.2010.12.05 2

Kaune, C., Nowinska, E., Paetau, A., \& Griep, M. (2013). Games for enhancing sustainability of year 7 maths classes in Indonesia: theory-driven development, testing and analyses of lessons, and of students' outcomes. Indonesian Mathematical Society Journal on Mathematics Education, 4(2), 129-156. Retrieved from http://ejournal.unsri.ac.id/index.php/jme/art icle/view/412

Khuziakhmetov, A. N., \& Gorev, P. M. (2017). Introducing learning creative mathematical activity for students in extra mathematics teaching. Bolema - Mathematics Education Bulletin, 31(58), 642-657. 
JURNAL GANTANG. September 2018; III(2): 109 - 116

p-ISSN. 2503-0671

e-ISSN. 2548-5547

https://doi.org/10.1590/1980-

$4415 \mathrm{v} 31 \mathrm{n} 58 \mathrm{a} 06$

Ladd, G. W., Ettekal, I., \& Kochenderfer-ladd, B. (2017). Peer victimization trajectories from kindergarten through high school: Differential pathways for children' $\mathrm{s}$ school engagement and achievement? Journal of Educational Psychology, 109(6), 1-16. https://doi.org/10.1037/edu0000177

Lambert, K., \& Spinath, B. (2018). Conservation abilities, visuospatial skills, and numerosity processing speed: association with math achievement and math difficulties in elementary school children. Journal of Learning Disabilities, 51(3), 223-235. https://doi.org/10.1177/0022219417690354

Lowe, N. K. (1988). Games and toys in the teaching of science and technology.

Makur, A. P., Prahmana, R. C. I., \& Gunur, B. (2018). Kemampuan berpikir tingkat tinggi, peserta OSK matematika tingkat SD, dan strategi think, talk, and write. Jurnal Pendidikan Matematika, 12(2), 23-32.

Mann, E. L. (2014). The search for mathematical creativity: identifying creative potential in middle the search for mathematical creativity: identifying creative potential in middle school students, (June). https://doi.org/10.1080/1040041090329740 2

Nafiah, Y. N., Suyanto, W., \& Yogyakarta, U. N. (2014). Penerapan model problem-based learning untuk meningkatkan keterampilan berpikir kritis dan the application of the problem-based learning model to improve the students critical thinking. Jurnal Pendidikan Vokasi, 4(c), 125-143.

Novitasari, W. (2016). Analisis kesultan belajar matematika anak usia 5-6 Tahun. Jurnal Eksakta, 1, 19-25.

Opolot-Okurut, C. (2010). Classroom learning environment and motivation towards mathematics among secondary school students in Uganda. Learning Environments Research, 13(3), 267-277. 